\title{
DEVELOPING DEVICES FOR CURRICULUM DEVELOPMENT AND LEARNING BIOLOGY COURSE BASED ON LENTERA OF MOODLE LEARNING MANAGEMENT SYSTEM AT UIN ALAUDDIN MAKASSAR
}

\author{
Muhammad Rapi' ${ }^{1}$, Ummul Hasanah $^{2}$, Nurul Sakinah Hijriah ${ }^{3}$ \\ 1,2,3Universitas Islam Negeri Alauddin Makassar \\ 1,2,3Jalan H. M. Yasin Limpo No. 36 Romang Polong-Gowa, Sulawesi Selatan \\ Email: mrapi@uin-alauddin.ac.id ${ }^{1}$, ummul.hasanah@uin-alauddin.ac.id², \\ nurulsakinahhijriah@gmail.com ${ }^{3}$
}

\begin{abstract}
:
This study aims to develop valid, practical, and effective lecture devices based on Lentera application of Moodle Learning Media System (LMS) for Curriculum Development and Learning course. The research type used was development research with the Plomp development model, consisting of phases 1) preliminary investigation, 2) design, 3) realization/construction, and 4) test, evaluation \& revision. The research subjects were 29 students of the fourth semester of Biology Education Study Program $(2019 / 2020)$. The instruments used in data collection are validation sheets, practicality questionnaires, and learning outcomes tests. The test results indicated valid, practical, and effective products. Therefore, the development product in this research can be used to accommodate students' learning in Curriculum Development and Learning Biology course.
\end{abstract}

\begin{abstract}
Abstrak:
Penelitian ini bertujuan untuk mengembangkan perangkat perkuliahan berbasis aplikasi LMS Moodle Lentera pada matakuliah Pengembangan Kurikulum dan Pembelajaran yang valid, praktis, dan efektif. Jenis penelitian menggunakan model pengembangan Plomp, yang terdiri atas fase 1) preliminary investigation, 2) design, 3)realization/construction, dan 4) test, evaluation \& revision. Subjek penelitiannya adalah 29 orang mahasiswa Prodi Pendidikan Biologi semester 4 (2019/2020). Instrumen yang digunakan dalam pengumpulan data yaitu lembar validasi, angket kepraktisan, dan tes hasil belajar. Hasil uji menghasilkan produk yang valid, praktis, dan efektif. Dengan demikian, produk pengembangan pada penelitian ini dapat digunakan dalam mengakomodasi pembelajaran mahasiswa pada matakuliah Pengembangan Kurikulum dan Pembelajaran Biologi.
\end{abstract}

\section{Keywords:}

Lecture Devices, Lentera, Moodle LMS, Curriculum Development, Learning Biology Course

How to Cite: Rapi, M., Hasanah, U., \& Hijriah, N. S. (2021). Developing devices for Curriculum Development and Learning Biology Course based on Lentera of Moodle Learning Management System at UIN Alauddin Makassar. Lentera Pendidikan : Jurnal Ilmu Tarbiyah dan Keguruan, 24(2), 303-315. https://doi.org/10.24252/lp.2021v24n2i12.

\section{INTRODUCTION}

Law Number 14 in 2005 of the Republic of Indonesia (RI) concerning teachers and lecturers states that educators are required to plan and professionally implement the 
learning process. The main task of lecturers as educators in higher education is emphasized in Article 28 of the Regulation of the Minister of Research, Technology and Higher Education of the Republic of Indonesia Number 50 in 2018 concerning national higher education standards, including lecturers' planning, implementing, and controlling the learning process, and implementing the evaluation of learning outcomes.

A learning plan is basically related to preparing and creating lecture devices used during the learning process. According to Trianto (2008: 121), learning materials or lectures include syllabus, lesson plans, activity sheets, learning outcomes tests, learning media, and textbooks. Meanwhile, the curriculum and learning team of Directorate of Learning and Student Affairs, Directorate General of Higher Education, Ministry of Education and Culture stated that the lecture device is a student learning activity plan outlined in Course Outline, called RPS.

Good learning planning factors can determine the success of students in accomplishing learning objectives. According to Chatib (2014: 193), the learning plan includes procedures, learning management, and short-term plans to estimate or project what educators and participants will do in the learning process.

The educational paradigm in the $21^{\text {st }}$ century is currently changing fundamentally,

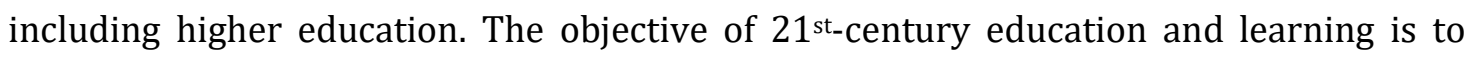
develop students' competencies who have information and communication technology literacy skills that include the capacity to think critically, creatively, and innovatively, as well as the ability to work in teams or collaborate. It is in line with Suwignjo (2018: 12) that education in the era of technological disruption significantly alters higher education practice. In the past, learning was carried out face-to-face. With the help of the internet, learning does not have to be face-to-face but rather online. Furthermore, Alhabahba in Nuriyanti, Utami \& Supriyanto (2013) recommends one form of a new paradigm in the educational system, namely e-learning.

Online learning, or e-learning, is currently popular. Miarso (2007: 235) states that elearning enables distance education via an internet network. In addition, the 21st century or digital era learning standards require educators and students to use technology in learning. The use of the internet as a medium and source of learning is done online. According to Herayanti, Fuaddunnazmi \& Habibi (2017), online learning is a form of media that uses the internet, computer networks, and other devices to deliver educational materials to students.

Online learning through the blended learning model uses the Learning Management System (LMS) application which includes features to support learning activities. One of the most widely used LMS software or applications in education today is the Modular ObjectOriented Dynamic Learning Environment (Moodle), which converts learning media to Web format (Suartama \& Tastra, 2014). Moodle is an open-source and free software application licensed under the GPL (General Public License). It may be distributed or modified under the terms of the GNU General Public License as published by the Free Software Foundation. Moodle can run on various web servers that support the PHP programming language and a database. It will run very well on an Apache web server with a MySQL database (Ahmadi, Sirojuddin \& Affandi, 2010: 31). 
According to Surjono (2010: 7), utilizing the Moodle application simplifies lecturers' management of lectures, specifically: compiling a syllabus, uploading lecture materials, assigning work to students, accepting students' works, creating tests/quizzes, assessing, monitoring students' activities, processing students' grades, and interacting with others. Students and fellow lecturers can interact through discussion forums, chat, video conferencing, and other conveniences. Using Moodle means building a system with the concept of e-learning or electronic learning (Bariyah \& Imania, 2018: 109).

The research findings of Herayanti, Fuaddunnazmi \& Habibi (2017) explain the benefits of Moodle application, which include being suited for use in online classes and as effective as the classroom learning process, simple, efficient, and easy to apply technology, and quickly installed on most PCs. Similarly, Riyadi, Nur \& Ismayati (2015: 61) found learning devices with Moodle are simple to use, effective in terms of students' answers, increased students' activities, and comprehensive learning outcomes. The research results of Hartawan, Tastra \& Pudjawan (2014) show differences in students' learning outcomes before and after using the Moodle-based e-learning portal.

Lentera used in Alauddin State Islamic University of Makassar is based on Moodle Learning Management system as the primary application. The developer of this e-learning application development has named it as Lentera (Learning Center Area).

Curriculum Development and Learning is a new course in Biology Education Study Program, based on the 2018 curriculum revision outcomes. This course is important for Biology Education students as prospective educators who will continue to deal with the development and dynamics of science. So the ability to develop curriculum and learning Biology is needed by students. Since this course is still in its infancy, it requires

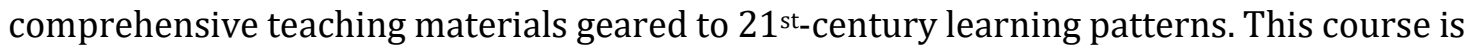
revealed in the fourth semester with two credits. The use of Lentera based on Moodle elearning in Biology Education Study Program represents a significant advancement expected to stimulate students' learning. Because e-learning can be conducted via a computer or an android device, students can interact directly with materials, participate in discussion forums, and take quizzes from any location.

\section{RESEARCH METHOD}

This study used development research with Plomp's development model (2013). The development phases include: (a) preliminary investigation, (b) design, (c) realization/construction, (d) test, evaluation \& revision, and (e) implementation. The instruments used were as follows: (a) validation sheets to obtain information about the quality of the resulting devices based on the experts' validation, (b) questionnaires to ascertain students' responses to lecture devices using online learning with Lentera based on Moodle application, and (c) learning outcomes through mid-semester exams and endsemester exams to find students' achievements after attending lectures using online learning with Lentera. Then, the data obtained were analyzed in three ways, namely validity, practicality, and effectiveness analyses. 


\section{Analysis of Validity Data}

Several expert validators assess the validity of the research product. Validity data were obtained from several instruments, namely the course outline (RPS), teaching materials, and learning outcomes tests. Aspects assessed in the validation of the course outline, namely 1) Identity; 2) Learning Outcome Indicators; 3) Course Description; 4) Content and Learning Activities; and 5) Time. Aspects assessed in the validation of module teaching materials are 1) Content Truth; 2) Content Update; and 3) Language. Aspects assessed in the practicality questionnaire validation are 1) Instructions, 2) Student Response, and 3) Language. Aspects assessed in the validation of the learning outcomes test are 1) Question Materials, 2) Construction, and 3) Language.

Determination of product validity, according to Nieveen (1999), if the product being developed is based on the correct theory and there is consistency between components, the product validity is assessed by the subject-matter experts. The validity category follows the criteria of Arsyad (2007: 144) as follows:

Table 1. Validity Criteria

\begin{tabular}{cc}
\hline Score & Criteria \\
\hline $3.5 \leq \mathrm{V} \leq 4$ & Very valid \\
\hline $2.5 \leq \mathrm{V}<3.5$ & Valid \\
\hline $1.5 \leq \mathrm{V}<2.5$ & Quite Valid \\
\hline $0 \leq \mathrm{V}<1.5$ & Invalid \\
\hline Notation: $\mathrm{V}=$ The validity average of all validators
\end{tabular}

\section{Analysis of Practicality Data}

The analysis of the lecture device practicality was obtained based on the results of students' response questionnaires after attending lectures with online learning using the Lentera application. Aspects assessed based on practicality questionnaires are 1) Aspects of Use, 2) Content, and 3) Appearance. The criteria for determining the level of practicality follow the questionnaire conversion of Ismawati, Rizki, Slamet \& Ismet (2018: 48) as follows:

Table 2. Practicality Criteria

\begin{tabular}{ccc}
\hline Achievement Level & Category & Criteria \\
\hline 5 & Very agree & Very Practical \\
\hline 4 & Agree & Practical \\
\hline 3 & Quite agree & Quite practical \\
\hline 2 & Disagree & Impractical \\
\hline 1 & Very disagree & Very impractical \\
\hline
\end{tabular}

\section{Analysis of Effectiveness Data}

Effectiveness data are derived from the students' activities and learning outcomes after attending lectures with online learning using Lentera application. Effectiveness data were gathered through the following activities: 1) completing summary assignments for each meeting, 2) participating in forum discussions, 3) taking quizzes, and 4) administering midterm and final semester exams. The obtained data is then analyzed descriptively. The criteria for students' learning outcome scores based on the educational guidelines of UIN Alauddin Makassar (2016: 45) are as follows: 
Table 3. Effectiveness Criteria

\begin{tabular}{ccc}
\hline No. & Score Category & Criteria \\
\hline 1 & $86-100$ & $\mathrm{~A}=4$ \\
\hline 2 & $76-85$ & $\mathrm{~B}=3$ \\
\hline 3 & $66-75$ & $\mathrm{C}=2$ \\
\hline 4 & $56-65$ & $\mathrm{D}=1$ \\
\hline 5 & $0-55$ & $\mathrm{E}=0$ \\
\hline
\end{tabular}

\section{RESULTS AND DISCUSSION}

The research results are described through phases of an initial investigation, design, realization/construction, test, evaluation and revision, and implementation. It discussed the process of developing lecture devices based on Lentera of Moodle application following Plomp's development steps from the initial investigation and design phases (Plomp, 2013). It also examined problems regarding the validity following the realization/construction phases, tests, evaluations, and revisions. Meanwhile, to answer the problem of effectiveness and acceptance of lecture devices, it followed the implementation steps.

\section{Initial Investigation Phases}

\section{Analysis of Curriculum}

Curriculum Development and Biology Learning course were added to the 2018 curriculum revision, which was based on the Rector's Decree Number 311 of 2018 concerning the Curriculum for Undergraduate Program in Faculty of Tarbiyah and Teacher Training at UIN Alauddin Makassar. The course of Curriculum Development and Learning is a component of faculty courses under the code of FTK220009.

Faculty component courses indicate that these courses must be programmed and passed by all students of Tarbiyah and Teacher Training Faculty of UIN Alauddin Makassar. When considering the allocation and distribution of courses, the Curriculum Development and Learning course is revealed in the fourth-semester students of Biology Education Study Program.

Curriculum Development and Learning course is a new offering that began in the fourth semester of the 2019/2020 academic year. The search results of learning devices for Curriculum Development and Learning course have not been found in Biology Education Study Program. As a result, learning devices are required to develop for completing the curriculum document.

\section{Analysis of Students' Characteristics}

The average age of students in batch 2019 who are currently in the fourth semester is $18-19$ years old. This age is approaching adulthood; the ability to think rationally is increasing, yet the ability to reason is becoming more abstract and idealistic. While the students' academic development is measured from the courses that have been programmed, the average of Biology Education Study Program students batch 2019 has completed a maximum of 66 credits (semester credit system) and temporarily programmed 23 credits in the current semester/ongoing research. Curriculum Development and Learning subject is one of the courses offered. 
Based on the research conducted by researchers on students who were used to test the product for Lentera of Moodle LMS application, it was found that all students of Biology Education Study Program had technological gadgets that supported the lecture process. Students own laptops and Android phones that can be used in the lecture process with Lentera of Moodle.

\section{Design Phase}

Course Outline (RPS) developed follows the RPS format used at Faculty of Tarbiyah and Teacher Training of UIN Alauddin Makassar. The RPS component consists of identities including; Faculty, Study Program, Course Name, Code, Course Cluster, Credits, Semester, Document Number, Lecturer, Head of Study Program, and Signature. Learning Outcomes include study program and course learning outcomes. The contents of the RPS include; course description, prerequisite, date, learning meeting, learning material, competency number/final skill. Learning covers; learning methods, student assignment units, assessment indicators, assessment scores, duration (minutes), and reference codes.

Modules or the teaching materials include learning activities from the first to the fourteenth meetings, meeting topics, learning outcomes, learning materials, conclusions, and bibliography. While each meeting's learning outcomes are assessed using a quiz in the form of a multiple choice test to see whether students have met their learning goals/achievements.

The entire course is designed in Lentera based on Moodle e-learning which is accessible online. Meanwhile, instruments in the form of RPS validation sheet formats, teaching materials/modules, learning outcomes tests (quiz, midterm, and final-semester exams), and students' response surveys were designed using Lentera of Moodle LMS to collect data on the results of the development of lecturing device.

\section{Realization/Construction Phases}

\section{Realization of Lecture Device}

The realization/construction phase is a continuation of phases 1 and 2 . It is the implementation of phase 1 and 2 activities. This realization resulted in a lecture product as Prototype-1. The resulting lecture sets comprise RPS, teaching materials/modules, learning outcomes tests (quiz, midterm, and final semester exams), and student response surveys. All realized/constructed items are uploaded to the LMS Moodle Lentera based elearning application through the following link: https://lentera.uinalauddin.ac.id/course/view.php?id=1396.

\section{Realization of Instrument}

Realization of assessment sheets or validation formats is in the form of RPS validation sheets, teaching materials/modules, learning outcomes tests (quiz, midterm, and final semester exams), and students' response questionnaires to Lentera of Moodle LMS application.

\section{Testing, Evaluation, and Revision Phases}

Testing, evaluation, and revision activities are focused on validating and revising prototype- 1 products to create prototype-2. Furthermore, the product was revised 
according to the data from the validator, resulting in prototype-2 being ready for implementation in online lectures.

\section{Validity Test}

Validation of the RPS: Three education professionals and practitioners, mainly their academics from Faculty of Tarbiyah and Teacher Training, assessed the produced RPS. The results of the assessment, analysis, and revision of RPS are summarized in Table 4 as follow:

Table 4. Results of RPS Validation Test

\begin{tabular}{cccc}
\hline No. & Assessment Aspect & Score & Category \\
\hline 1 & Identity of RPS & 4 & Very valid \\
\hline 2 & Learning achievement indicators & 3.7 & Very valid \\
\hline 3 & Course description & 3.7 & Very valid \\
\hline 4 & Learning contents and activities & 3.8 & Very valid \\
\hline 5 & Duration/time & 4 & Very valid \\
\hline & Average & $\mathbf{3 . 8 4}$ & Very valid \\
\hline
\end{tabular}

Validation of Teaching Materials/Modules: The module of teaching materials for the Curriculum Development course has thirteen topics/learning materials. Table 5 below summarizes the results of the validators' assessment of the teaching materials/modules.

Table 5. Results of Teaching Material/Module Validity Test

\begin{tabular}{cccc}
\hline No. & Assessment Aspect & Score & Category \\
\hline 1 & content authenticity & 3.6 & Very valid \\
\hline 2 & content novelty & 3.4 & Valid \\
\hline 3 & Language & 3.7 & Very valid \\
\hline & Average & $\mathbf{3 . 6}$ & Very valid \\
\hline
\end{tabular}

Based on Table 5, the average validity of the learning outcomes test is 3.6 from the ideal score of 4.0. If this score is confirmed on the validity criteria $(3.5 \leq \mathrm{M} \leq 4.0)$, it is concluded that the score is very valid. It indicates that the teaching materials for learning outcomes meet the criteria of validity.

\section{Implementation Phase}

\section{Practicality Test}

The level of practicality of online lectures based on the Lentera application is determined by collecting students' responses using a questionnaire instrument at the last lecture meeting of the semester. SPSS version-23 software was used to analyze students' responses regarding the practicality of Lentera application.

Based on the analysis results, students' average practicality score was 83.66 from the ideal score of 120 . The highest score obtained was 105, and the lowest score obtained was 62. If the response scores about the practicality of students attending lectures are classified into four categories, the frequency distribution and percentage are as shown in Table 6 as follow. 
Table 6. Distribution of Frequency and Percentage of Online lecture Practicality based on Lentera Application

\begin{tabular}{ccccc}
\hline No. & Score & Frequency & Percentage & Category \\
\hline 1 & $102<\mathrm{X} \leq 120$ & 1 & 3.4 & Very practical \\
\hline 2 & $78<\mathrm{X} \leq 101$ & 19 & 65.5 & Practical \\
\hline 3 & $54<\mathrm{X} \leq 77$ & 9 & 31 & Less practical \\
\hline 4 & $30<\mathrm{X} \leq 53$ & 0 & 0 & Very impractical \\
\hline
\end{tabular}

The data analysis in Table 6 revealed that students' responses to the practicality of lecture devices using Lentera application ranged from very practical, practical, and less practical. However, students stated that it was practical in general.

\section{Effectiveness Test}

The effectiveness of learning devices is determined by the students' achievement of cognitive learning outcomes after attending Curriculum Development and Learning course using an online learning device based on the LMS Moodle Lentera. Students' competencies are assessed by the scores obtained in the midterm and the end of semester exams.

SPSS version-23 software was used to process the analysis results of students' learning outcomes. The analysis of midterm exam scores revealed a mean score of 65.03 out of the ideal score of 100 . The highest score obtained was 90.00, and the lowest score was 0 . Table 7 summarizes the distribution of frequency and percentage of students' learning outcomes.

Table 7. Distribution of Frequency and Percentage of Midterm Exam Scores

\begin{tabular}{ccccc}
\hline No. & Score & Frequency & Percentage & Category \\
\hline 1 & $85-100$ & 8 & 27.6 & Very high \\
\hline 2 & $65-84$ & 10 & 34.5 & High \\
\hline 3 & $45-64$ & 5 & 17.2 & Moderate \\
\hline 4 & $25-45$ & 4 & 13.8 & Low \\
\hline 5 & $0-24$ & 2 & 6.9 & Vey low \\
\hline
\end{tabular}

Based on Table 7, there were eight students, or $27.6 \%$, who scored in the very high category. Ten students, or $34.5 \%$, were high category. Five students, or $17.2 \%$, were in the moderate category. Four students, or $13.8 \%$, were low category. Besides, two students, or $6.9 \%$, were in the very low category.

Furthermore, in the second section of the lecture, a final semester exam assesses students' final competence while participating in online lectures with LMS Moodle Lentera. The analysis of learning outcomes for end-of-semester exams revealed an average score of 76.97 of the ideal score of 100 , with the highest score obtained was 96.00 , and the lowest score obtained was 17.00. If students' learning outcomes are classified, the frequency and percentage are distributed as indicated in Table 8. 
Tabel 8. Distribution of Frequency and Percentage of Final Semester Exam Scores

\begin{tabular}{ccccc}
\hline No. & Score & Frequency & Persentage & Category \\
\hline 1 & $85-100$ & 14 & 48.3 & Very high \\
2 & $65-84$ & 10 & 34.5 & High \\
3 & $45-64$ & 3 & 10.3 & Moderate \\
4 & $25-45$ & 1 & 3.4 & Low \\
5 & $0-24$ & 1 & 3.4 & Very low \\
\hline
\end{tabular}

Based on Table 8 , there were 14 students or $48.3 \%$ in the very high category. Ten students, or $34.5 \%$, were high category. Three students, or $10.3 \%$, were in the moderate category. Besides, each of 1 student, or $3.4 \%$, was in the low and very low categories.

It is known that there were 14 students or $48.3 \%$ who scored in the very high category, ten students or $34.5 \%$ in the high category, three students or $10.3 \%$ in the moderate category. In addition, the low and very low categories were one student or $3.4 \%$, respectively.

\section{Validity Level of Learning Device based on Lentera of LMS Moodle}

Validation of the Lentera application-based lecture device in Curriculum Development and Learning course consists of RPS assessment, teaching materials/modules, quizzes, and learning outcomes tests.

The validation results of experts and practitioners on RPS and teaching materials/modules developed by the researchers obtained average scores of 3.83 and 3.6, respectively, with a very valid category. The online practicality response questionnaire based on Lentera application received an average score of 3.8 in the very valid category. The developed quizzes and learning outcomes tests averaged 3.4 with a valid category following the validators' review.

Based on the validators' assessment results, the teaching devices and instruments developed by the researchers are eligible for use in a study. According to Nieveen (1999), the tools and instruments used in research development must meet the latest knowledge. Lecture devices based on Lentera application with instruments developed by researchers fulfil the latest criteria. The latest criteria means are (1) lecturing devices developed by researchers following Indonesian National Curriculum Framework (KKNI) level 6; (2) fast technological developments encourage educators and educational institutions to develop and utilize e-learning systems, including the use of Moodle-based e-learning developed by Information Technology Center and Database of UIN Alauddin Makassar, named Learning Center Area (Lentera); (3) The Covid-19 pandemic which affected all countries worldwide changed the educational process from face-to-face to distance learning using information technology.

Although the overall assessment of the instruments met the validity requirements, there were still suggestions that need to be revised, namely; (1) describe in detail the student task units in RPS; (2) include summaries in teaching materials/modules; and (3) create quizzes and learning outcome tests using HOTS questions. The development of HOTS questions is a technique for assessing higher-order thinking skills such as logic and reasoning, assessment analysis and creation, as well as problem-solving and decision making (Brookhart in Kurniati et al., 2016: 143). 


\section{The Practical Level of Lecture Devices Based LMS Moodle Lentera}

The practical aspects of the products developed by the researchers include (1) the use of Lentera application, (2) the content of the presentation, and (3) its appearance.

The average score obtained from the practical response analysis of online lectures using Lentera application was $83.66 \%$. When the frequency distribution category was presented, the level of practicality of the products used by students in lectures was found to be $3.4 \%$ with very practical, $65.5 \%$ with practical, $31 \%$ with less practical, and none with very impractical categories. The practicality generated in development research, according to Van den Akker (1999), refers to users or experts in considering that the products used are attractive, useful, and can be used by students under normal conditions. Nieveen had a similar opinion, stating that development research is considered practical if the lecture device's user interface is simple to operate and requires minimal reaction (Riyadi, Nur \& Ismayati, 2015: 63).

The practicality of the lectures based on Lentera application applied to fourthsemester students of Biology Education Study Program is generally in the practical category. However, it still needs attention because $31 \%$ of students believe it is practical. The analysis and identification results of the practicality of the developed product reveal that there are obstacles to use Lentera application. The following are the obstacles identified by students using Lentera application that require attention: (1) There is no difference between online and face-to-face lectures; (2) Face-to-face lectures are more efficient in class than distance lectures; (3) Internet access at home does not support Lentera application network; and (4) Lentera application online lectures make it difficult for students to interact with fellow students and lecturers. These problems are commonplace in online learning, so one solution is through blended learning. This blended learning combines online and offline lectures to facilitate students who are constrained in online learning.

The findings of this study are in line with the research of Fahmi \& Cipta (2018: 6), who found that challenges associated with online lectures, such as motivation to complete learning, assignment completion, and unstable network access, can be addressed through face-to-face learning. The combination of online and face-to-face lectures is called blended learning. It is a type of learning model that uses information and communication technology, particularly the internet and websites, to organize online learning that is used to support offline or face-to-face learning activities.

The results of this study also corroborate the research findings of Handayanto, Rasiman, Supandi, \& Ariyanto (2015: 47) that e-learning devices enable students to participate in and communicate during lectures without having to meet face to face. Students simply need to visit the e-learning website to determine whether there are assignments or not and can immediately submit their assignments. They also might seek out other educational resources as reference material.

\section{The Effectiveness of Lecture Devices Based on LMS Moodle Lentera}

The effectiveness of lecture devices based on Lentera application in Curriculum Development and Learning course is related to developing lesson plans, teaching 
materials/modules, and learning outcomes tests. Students' learning outcomes from midterm and final semester exams serve as indicators of efficacy.

Reigeluth in Riyadi, Nur \& Ismayati (2015) states that an essential aspect of determining the level of effectiveness of a product is applying a theory or model in a particular situation. Effectiveness is defined as the degree to which the learning results correspond to the learning objectives.

Based on Reigeluth's view, it was found that students' learning outcomes after taking the midterm exam obtained an average score of 63.03 . When the scores were classified, it was found that $27.6 \%$ with very high, $34.5 \%$ were with high, $17.2 \%$ with moderate, and $6.9 \%$ were with low categories. Thus, the category of mid-semester examination results obtained was in the high category. Additionally, students' learning outcomes following the completion of the final semester exam obtained averaged 76.07. If the scores were classified, it was found that $48.3 \%$ with very high, $34.5 \%$ with high, $10.3 \%$ with moderate, and $3.4 \%$ were with low categories. Therefore, it is concluded that the category of students' learning outcomes after taking the final semester exam is in the very high category.

Based on the learning outcomes obtained by students in the midterm and final semester exams, they still vary from very high, high, and low. However, when considered the learning outcomes, it was discovered that the midterm exam results were in the high category and the final semester exam results were in the very high category. The findings of this study indicated that the lecture devices based on Lentera application in Curriculum Development and Learning course developed by the researchers were effectively used.

The findings of this study are in line with research conducted by Nuriyanti, Utami, Supriyanto (2013), who reported that the application of learning using Moodle-based elearning media received positive responses from students and teachers and effectively improved students' learning outcomes.

\section{CONCLUSION}

The validity level of the Course Outline (RPS) was in the very valid category, with an average score of 3.83. The average scores of teaching materials/modules and practicality response questionnaires were 3.6 and 3.8, with very valid categories, respectively. The average score for quizzes and learning outcomes was obtained 3.4 with a valid category. The level of practicality of the product developed was $65.5 \%$, with a very practical category. The average scores of effectiveness level based on lecture devices of Lentera application in the midterm and final semester exams were 63.03 and 76.07, respectively. Based on these results, the developed Moodle Lentera LMS can be used in online learning because it is efficient and easy to apply on a computer or smartphone. In addition, the use of Moodle Lentera LMS improved student learning outcomes.

\section{REFERENCES}

Ahmadi, C., Sirojuddin, A., \& Affandi, A. (2010). Aplikasi Mobile Learning Berbasis Moodle dan MLE Pada Pembelajaran Kedokteran. Seminar Nasional Aplikasi Teknologi Informasi (SNATI). https://journal.uii.ac.id/Snati/article/view/1858/0. 
Arsyad, N. (2007). Model Pembelajaran Matematika yang Menumbuhkan Kemampuan Metakognitif untuk Menguasai Bahan Ajar. Disertasi Tidak Diterbitkan. Surabaya: PPS Universitas Negeri Surabaya.

Bariyah, S. H., \& Imania, K. A. N. (2018). Implementasi Blended Learning Berbasis Moodle pada Jurusan Pendidikan Teknologi Informasi. Jurnal Petik, 4(2), 106-113. https://doi.org/10.31980/jpetik.v4i2.10.

Chatib, M. (2014). Gurunya manusia: Menjadikan Semua Anak Spesial dan Semua Anak Juara. Mizan-Kaifa.

Fahmi, M. H., \& Cipta, B. S. I. (2018). Pengembangan Blended Learning Berbasis Moodle (Studi Kasus Di Universitas Islam Raden Rahmat Malang). Jurnal Teknologi Terapan: G-Tech, 2(1), 106-113. https://doi.org/10.33379/gtech.v2i1.328.

Handayanto, A., Rasiman, R., Supandi, S., \& Ariyanto, L. (2015). Pembelajaran E-Learning Menggunakan Moodle pada Mata Kuliah Metode Numerik. Jurnal Informatika UPGRIS, 1(1 Juni). https://doi.org/10.26877/jiu.v1i1\%20Juni.808.

Hartawan, I. K. A., Tastra, I. D. K., \& Pudjawan, K. (2014). Pengembangan Portal E-Learning Berbasis Moodle pada Mata Pelajaran Fisika Kelas X di SMA Dwijendra Denpasar. Jurnal Edutech Undiksha, 2(1). http://dx.doi.org/10.23887/jeu.v2i1.3588.

Herayanti, L., Fuaddunnazmi, M., \& Habibi, H. (2017). Pengembangan Perangkat Pembelajaran Fisika Berbasis Moodle. Jurnal Pendidikan Fisika Dan Teknologi, 3(2), 197-206. http://dx.doi.org/10.29303/jpft.v3i2.412.

Ismawati, Rizki Lia; Slamet, Adeng; Ismet, I. (2018). Pengembangan Media Pembelajaran Berbasis Moodle pada Mata Pelajaran Biologi di Sekolah Menengah Atas. Jurnal Inovasi Pendidikan, 8(2), 44-55. inovpend.ejournal.unsri.ac.id/index.php/sij-inovpend/article/view/20.

Kurniati, D., Harimukti, R., \& Jamil, N. A. (2016). Kemampuan Berpikir Tingkat Tinggi Siswa SMP di Kabupaten Jember dalam Menyelesaikan Soal Berstandar PISA. Jurnal Penelitian dan Evaluasi Pendidikan, 20(2), 142-155. http:// dx. doi.org/10.21831/pep.v20i2.8058.

Miarso, Y. (2007). Menyemai Benih Teknologi Pendidikan, cet III. Jakarta: Kencana Prenada Media Group.

Nieveen, N. (1999). Prototyping to Reach Product Quality. In Design Approaches and Tools in Education and Training (pp. 125-135). Springer. https://link.springer.com/content/pdf/10.1007/978-94-011-4255-7_10.pdf.

Nuriyanti, Desinta Dwi; Utami, Nur Rahayu; Supriyanto, S. (2013). Pengembangan ELearning Berbasis Moodle sebagai Media Pembelajaran Sistem Gerak di SMA. Journal of Biology Education, 2(3). https://journal.unnes.ac.id/sju/index.php/ujbe/article/vi ew/3096.

Plomp, T. (2013). Educational design research: An Introduction. Educational Design Research, 11-50. https://research.utwente.nl/files/14472302/Introduction_20to_2 0education_20design_20research.pdf.

Riyadi, R. A., Nur, M., \& Ismayati, E. (2015). Pengembangan Perangkat Pembelajaran Berbasis E-Learning Moodle dengan Model Pengajaran Langsung di SMKN 2 Tarakan. Pendidikan Vokasi: Teori dan Praktik, 3(01). https://www.neliti.com/id/publications/247052/pengembangan-perangkatpembelajaran-berbasis-e-learning-moodle-dengan-model-peng. 
Suartama, I. K., \& Tastra, I. D. K. (2014). E-Learning Berbasis Moodle. Yogyakarta: Graha Ilmu.

Surjono, H. D. (2010). Membangun Course E-Learning Berbasis Moodle. Universitas Negeri Yogyakarta.

Suwignjo, P. (2018). Bukan Sekadar Mengonlinekan Paparan Perkuliahan. Ristekdikti, 1213. https://www.brin.go.id/wp-content/uploads/2018/05/Layout-MajalahRistekdikti-I-2018-Update-Page-20180426.pdf.

Trianto, M. P. (2008). Mendesains Pembelajaran Kontekstual di Kelas. Jakarta: Kencana Prenada Media Group.

UIN Alauddin Makassar. (2016). Pedoman Edukasi Universitas Islam Negeri Alauddin Makassar. UIN Alauddin.

Van den Akker, J. (1999). Principles and Methods of Development Research. In Design Approaches and Tools in Education and Training (pp. 1-14). Springer. https://link.springer.com/chapter/10.1007/978-94-011-4255-7_1. 